\title{
Is Salt Intake Hidden Risk for Rural Population: Case Study Village of Sjeverovac, County Sisačko- Moslavačka?
}

\author{
Ksenija Vitale ${ }^{1}$, Slavica Sović ${ }^{1}$, Aleksandar Džakula ${ }^{1}$, Adis Keranović ${ }^{1}$ and Bojan Jelakoviće ${ }^{2}$ \\ ${ }^{1}$ University of Zagreb, School of Medicine, »Andrija Štampar« School of Public Health, Zagreb, Croatia \\ ${ }^{2}$ University of Zagreb, Zagreb University Hospital Center, Zagreb, Croatia
}

\begin{abstract}
A B S T R A C T
Nutritional habits between urban and rural population differ as much as life style and socioeconomic standards of these populations. In Croatia, rural populations are mostly live stock producers. Their nutrition frequently depends on their own production, which includes high quantity of cured meat products, eggs and dairy products. Data were obtained from longitudinal the Croatian Adult health Survey and pilot cross-sectional survey in three villages in Sisačko-moslavačka county. Our findings show that there is no great difference between urban and rural population regarding salt intake. The difference is in the type of food and food preparation, as well as life style. We propose combination of more culturally and socially sensitive questionnaires along with analytical methods that include biological matrix, such as 24-hour urine collection.
\end{abstract}

Key words: salt intake, rural population, 24-hour urine collection, Croatia

\section{Introduction}

Throughout the history daily salt intake was less than $1 \mathrm{~g}$, but when beneficiary properties of salt as a preserving agent were discovered salt became important economical factor. With introduction of processed food, semi prepared meals, fast food and snacks, the use of salt dramatically increased. Salt is used as preservative agent but also as a flavor enhancing agent, due to the fact that most of such a food has been produced from low quality raw materials. Various researches show that average daily salt intake varies between 12 and $16 \mathrm{~g}$, although for normal body functioning only 4 to $6 \mathrm{~g}$ are needed. Sodium is principal cation in the extracellular fluid with main function related to volume, water balance and membrane cell potential ${ }^{1}$. Epidemiological studies have shown that excessive salt intake is important and significant risk factor for hypertension, stroke, left ventricular hypertrophy, proteinuria, osteoporosis, nephrolithiasis and possible stomach cancers. Some authors argue that indirectly salt contributes to the weight gain through higher water consumption. Salt intake is higher than recommended in majority of developed and developing world ${ }^{1}$. So far data on salt intake in Croatia are limited.

\section{Differences in Nutritional Habits in Rural and Urban Population}

Nutritional habits between urban and rural population differ as much as life style and socioeconomic standards of these populations. Some studies in Croatia have shown that both man and women with lover education in rural areas have higher risk of obesity than man and women in urban areas due to the hidden fat in cured meat products. In addition due to the high quantity of salt in such products they have higher risk of cardiovascular diseases ${ }^{2}$. On the other hand the main source of salt in urban populations is highly processed food, semi prepared food and bread, along with salty snacks ${ }^{3-7}$. Recent studies identified soft drinks as well are related to salt intake ${ }^{8}$. The major reason for the differences in nutritional habits is fact that main income source in rural areas is food production. In Croatia, rural populations are mostly live stock producers. Their nutrition frequently depends on their own production, which includes high quantity of cured meat products, eggs and dairy products. More ever, some of traditional technologies for

Received for publication September 1, 2011 
cheese and cured meat production with high salt concentration are patented today, and protected as autochthon Croatian product.

The aim of this study was to investigate is salt intake hidden risk for chronic diseases in rural population.

\section{Materials and Methods}

Data for this study were obtained from the Croatian Adult health Survey (CAHS) in 2003 followed by 2008 . Further details on CAHS are provided elsewhere ${ }^{9}$. Sample consisted of cohort 3229 participants who were interviewed in both years. Food habits were described with 22 questions in CAHS, but in order to evaluate salt consumption there was only one question: Do you add salt to the meal at the table? 3221 participants answered this question. Data for case study were obtained from pilot cross-sectional survey from January to April 2010 in three villages in Sisacko-moslavacka county. Participants included in the survey were aged 18 years or older; sample consisted of all inhabitants present at their households at the moment of survey. Sample was composed on door to door basis. Exclusion criteria were pregnancy, terminal illness and upper limbs amputations. Out of 125 inhabitants 18 years or older 26 participated in the urinary sodium measurement study (participation rate 20.8\%), 17 (65.3\%) female and 9 (34.6\%) male. Besides collecting urine, people completed a questionnaire and blood pressure was measured. For this case study we focused on two questions about own salt intake and knowledge which food has highest salt concentration. Salt intake was estimated by 24-hour urine collection that is quick, simple diagnostic test that is considered to be the "gold standard « for sodium intake measure because it can capture $85-90 \%$ of ingested sodium ${ }^{1}$. This method presents the advantage of being unaffected by subjective reporting of dietary intakes (REF-WHO). Samples were analyzed in the laboratory of Clinical Hospital Centre Zagreb. Amount of salt intake (in grams) was calculated from sodium (mmol) divided with denominator 17,1. Amount of sodium (in milligrams) was calculated by multiplication of sodium ( $\mathrm{mmol}$ ) by 23 .

Study protocol was approved by bioethical committee of Medical School, University of Zagreb, and all participants gave informed consent.

Data for continuous variables were expressed as mean $( \pm)$ standard deviation (SD), Pearson's $\chi^{2}$-test was used for comparison of frequencies. As statistically significant was considered $P<0.05$. Data were analyzed using Statistica statistical package (Stat Soft INC, Tulsa, OK, USA).

\section{Results}

Results of questions in (CAHS) are shown in Tables 1 and 2 .

There is no statistically significantly difference between urban and rural population regarding adding salt at the table. However, when we analyzed differences be-
TABLE 1

ADDING SALT TO THE MEAL IN RURAL AND URBAN POPULATION

\begin{tabular}{lrcc}
\hline & Never N/\% & Sometimes N/\% & Always N/\% \\
\hline Urban & $1053 / 54.9 \%$ & $731 / 38.1 \%$ & $133 / 6.9 \%$ \\
Rural & $670 / 53.4 \%$ & $507 / 40.4 \%$ & $78 / 6.2 \%$ \\
\hline
\end{tabular}

tween genders within each location of living results have shown that in both urban $\left(\chi^{2}=24.19 \mathrm{p}<0.001\right)$ and rural $\left(\chi^{2}=36.44 \mathrm{p}<0.001\right)$ settings significant difference exists, and in both cases male participants add more salt at the table.

TABLE 2

ADDING SALT TO THE MEAL REGARDING GENDER

\begin{tabular}{lrcc}
\hline & Never N/\% & Sometimes N/\% & Always N/\% \\
\hline Male & $462 / 45.5 \%$ & $449 / 44.2 \%$ & $104 / 10.2 \&$ \\
Female & $1281 / 58.1 \%$ & $814 / 36.9 \%$ & $111 / 5.0 \%$ \\
\hline
\end{tabular}

When analyzed by gender results have shown that there is statistically significant difference between males and females $p=0.000$, and that, male participants add more salt than female. On the other hand when each gender is analyzed regarding place of living it turned out that there is no statistically significant difference between genders either in urban or rural setting.

Most of the participants had higher than recommended values of $\mathrm{NaCl} 9$ out of 17 females and 6 out of 9 males. However, results show some downsides of 24 -hour urine collecting as a method. Some of the urine samples were obviously under collected so results cannot be fully considered. Limitations of the method are high participation burden along with problems of completeness and time accuracy. Regardless downsides, results are indicating trend of high salt intake. These results correspond with other literature findings ${ }^{1}$. Response rate of $20 \%$ that might seem small should be viewed in regard of overall participant's age (mean age $65.4 \pm 16.2$ male and $65.7 \pm 14.3$ female), which makes most of them incapable for accurate urine collection (Table 3.).

\section{Discussion}

Some studies show that salt intake in continental rural population is 1.8 times higher than recommended by $\mathrm{WHO}$, and higher in man than woman ${ }^{10}$. When rural and urban populations were compared there was no difference between two regions in salt intake, but in urban population men were consuming more salt than women. According to this study average salt intake was $13.3 \pm 4.3$ $\mathrm{g}$ per day for man and $10.2 \pm 4.2 \mathrm{~g}$ per day for women ${ }^{11}$. All this data confirm our findings that there is no great difference between urban and rural population regarding salt intake. The difference is in the type of food and food 
TABLE 3

QUANTITIES OF NACL AND NA CALCULATED FROM 24-HOUR URINE COLLECTION METHOD.

\begin{tabular}{|c|c|c|c|}
\hline & Sodium & $\mathrm{NaCl}(\mathrm{g})$ & $\mathrm{Na}(\mathrm{g})$ \\
\hline \multicolumn{4}{|l|}{ Female } \\
\hline Participant 1 & 196 & 11.46 & 4.50 \\
\hline Participant 2 & 262 & 15.32 & 6.02 \\
\hline Participant 3 & 139 & 8.12 & 3.19 \\
\hline Participant 4 & 174 & 10.17 & 4.00 \\
\hline Participant 5 & 112 & 6.54 & 2.57 \\
\hline Participant 6 & 67 & 3.91 & 1.54 \\
\hline Participant 7 & 72 & 4.21 & 1.65 \\
\hline Participant 8 & 86 & 5.02 & 1.97 \\
\hline Participant 9 & 48 & 2.80 & 1.10 \\
\hline Participant 10 & 177 & 10.35 & 4.07 \\
\hline Participant 11 & 78 & 4.56 & 1.79 \\
\hline Participant 12 & 71 & 4.15 & 1.63 \\
\hline Participant 13 & 133 & 7.77 & 3.05 \\
\hline Participant 14 & 95 & 5.55 & 2.18 \\
\hline Participant 15 & 235 & 13.74 & 5.40 \\
\hline Participant 16 & 79 & 4.61 & 1.81 \\
\hline Participant 17 & 135 & 7.89 & 3.10 \\
\hline \multicolumn{4}{|l|}{ Male } \\
\hline Participant 1 & 101 & 5.90 & 2.32 \\
\hline Participant 2 & 33 & 1.92 & 0.75 \\
\hline Participant 3 & 198 & 11.57 & 4.55 \\
\hline Participant 4 & 69 & 4.03 & 1.58 \\
\hline Participant 5 & 128 & 7.48 & 2.94 \\
\hline Participant 6 & 167 & 9.76 & 3.84 \\
\hline Participant 7 & 176 & 10.29 & 4.04 \\
\hline Participant 8 & 213 & 12.45 & 4.89 \\
\hline Participant 9 & 283 & 16.54 & 6.50 \\
\hline
\end{tabular}

preparation, as well as life style. Often urban life style is perceived as unhealthy, hectic with poor nutritional habits, as oppose to rural or small town life style that kept slower way of living and traditional nutritional habits. Most of the studies in Croatia have shown that high salt intake is dominantly through industrial products, fast food and leisure food ${ }^{3-5}$. Studies conducted worldwide support that findings, stating that $75 \%$ of salt intake comes from processed food or food eaten away from home ${ }^{6,7}$. Now we can see that traditional nutritional habits are not necessary healthy, and food that is processed on small family owned farms is not necessary less industrialized. Paradigm of homegrown produce and health should be looked at with certain caution. Many studies have shown that home produced food is not perceived as a source of salt intake at all. Participants in our study mostly consume food prepared at home, did not know if their intake is normal, and did not know main sources of salt intake in every day meal. Few of them listed cured meat and bread. Cured meat is mostly perceived as source of fat, rather than salt. Other studies of rural population in Croatia inquiring about sources of salt intake revealed that more than $50 \%$ of both men and women think it is cured meat, only $0.5 \%$ recognizes bread as source of salt ${ }^{11}$.

Traditional is often mistaken for the quality, when in fact traditional recipes and processes reflect, lack of resources and better technologies, way of living of rural population and hardship that still exists. Pork meat, which is mostly used for curing, is the cheap meat easy to grow in any climatic conditions. In many areas without possibility to buy food people rely on what they can grow. Their diet is mostly meat, conserved traditionally with salt, for long periods of shelf life. In the area, which is suitable mostly for animal husbandry, vegetable and grain is grown for household use only, which in general makes diet without variety. If they want to stock some food it is only canned goods, which are again saturated with salt. At the seaside, small blue fish is salted in order to last through the season closed for fishing

\section{We Can Conclude?}

Intervention studies at population level have shown that decrease in salt intake could decrease values of blood pressure in the population. It is estimated that decrease of $6 \mathrm{~g}$ of salt daily could decrease incidence of cerebral stroke for $24 \%$ and coronary disease for $18 \%$. Reduction of salt intake is considered as cost effective measure and if applied at the individual level and industrial level it could diminish number of deaths for 8.5 million. Body of evidence for reducing salt is stronger than any other non-pharmaceutical treatment ${ }^{12}$.

For the studies that are aimed for intervention more details on target population should be obtained. The CAHS questionnaire that was used could give some misleading results and false negatives due to the standardized questions that are more suitable for the urban population. As a banal example we can indicate questions on the consumption of fast food, snacks and soft drinks, which are perceived as main source of the salt intake and which are almost unavailable in the rural settings. These types of foods and drinks are not likely to be consumed in rural settings even more where mostly elderly population live. We propose combination of more culturally and socially sensitive questionnaires along with analytical methods that include biological matrix, such as 24-hour urine collection.

\section{Acknowledgements}

This study was supported by the Croatian ministry of Science, Education and Sport, grant number 108-1080135-0264 . 


\section{R E F E R E N C E S}

1. WORLD HEALTH ORGANISATION (2006) Reducing salt intake in populations: Report of a WHO forum and Technical meeting 5-7 October 2006, Paris, France, accessed february 2011. Available from URL: http://www. who.int/dietphysicalactivity/reducingsaltintake_EN.pdf. — 2 MUSIĆ MILANOVIĆ S, Demografske, bihevioralne i socio-ekonomske odrednice debljine odraslih u Hrvatskoj. Accessed February 2011. Available from URL: http://medlib.mef.hr/932/01/Music-Milanovic_S_disertacija_rep_932.pdf - 3. JELAKOVIĆ B, VUKOVIĆ I, REINER Z, Ācta Med Croat, $6 \overline{4}$ (2010);105. - 4. JELAKOVIĆ B, KAIĆ-RAK A, MILICIĆ D, PREMUZIĆ V, SKUPNJAK B, REINER Z, Lijec Vjesn, 131 (2009):87. 5. JELAKOVIĆ B, ZELJKOVIĆ-VRKIĆ T, PEĆIN I, DIKA Z, JOVANOVIĆ A, PODOBNIK D, SMUC T, GAMBERGER D, KATIĆ K, KASNER
M, KUZMANIĆ D, Acta Med Croat, 61 (2007); 287. - 6. BROWN IJ, TZOULAKI I, CANDELIAS V, ELLIOTT P, Int J Epidemiol, 38 (2009);791. 7. HE FJ, MACGREGOR MA, J Hum hypertension, 23 (2009);363. — 8. HE FJ, MARRERO NM, MACGREGOR GA, Hypertension, 51(2008);629. - 9. VULETIĆ S, POLAŠEK O, KERN J, STRNAD M, BAKLAIĆ Ž, Coll. Antropol, 33 (2009);3. — 10. DIKA Ž, PEĆIN I, PEIĆ AM, JELAKOVIĆ B, HČJZ, (2010) 6:21 Accessed June 2011. Available from URL: http:// www. hcjz. hr/pr.php?id=14117. - 11. PREMUŽIĆ V, ERCEG I, JOVANOVIĆ A, REINER Ž, JELAKOVIĆ B, HČJZ (2010) 6:21. Accessed june 2011. Available from URL: http://www.hcjz.hr/clanak.php?id=14115\& rnd $=-12$. HE FJ, MACGREGOR GA, Prog Cardiovasc Dis, 52 (2010);363.

\section{K. Vitale}

University of Zagreb, School of Medicine, "Andrija Štampar « School of Public Health, Rockefeller 4, 10000 Zagreb, Croatia

e-mail:kvitale@snz.hr

\section{UNOS SOLI, SKRIVENI RIZIK ZA RURALNU POPULACIJU: PRIKAZ SLUČAJA SELO SJEVEROVAC, SISAČKO MOSLAVAČKA ŽUPANIJA}

\section{S A Ž E T A K}

Prehrambene navike između urbane i rurlane populacije razlikuju se kao i životni stilovi i socioekonomski statusi tih populacija. U Hrvatskoj ruralne populacije su pretožno uzgajivači stoke, a njihova prehrana ovisi o vlastitoj proizvodnji što uključuje veće količine mesnih prerađevina, jaja i mliječnih proizvoda. Podaci za ovu studiju su dobiveni iz Hrvatske zdravstvene ankete te pilot projekta u tri sela u Sisačko moslavačkoj županiji. Rezultati su pokazali da nema razlike između urbane i ruralne populacije u unosu soli, ali razlika postoji u vrsti namirnica i načinu pripreme. Smatramo da bi upitnici morali biti socijalno i kulturološki osjetljiviji te da je potrebno uključiti i analitičke metode bioloških matrica, a sve u cilju dobivanja što vjerodostojnijih rezultata. 